\title{
MONITORING AND ANALYZING OF THE ATTACKS OF THE FOOTBALL TEAM
}

\author{
Viktor Kostiukevych ${ }^{1 \mathrm{ABCDE}}$, Natalia Shchepotina ${ }^{1 \mathrm{ABCDE}}$, Tetiana Vozniuk ${ }^{1 \mathrm{ABCDE}}$ \\ ${ }^{1}$ Vinnytsia Mykhailo Kotsiubynskyi State Pedagogical University \\ Authors' Contribution: A - Study design; B - Data collection; C - Statistical analysis; D - Manuscript Preparation; E - Funds Collection
}

Corresponding Author: Viktor Kostiukevych, e-mail: kostykevich.vik@gmail.com

Accepted for Publication: June 20, 2020

Published: June 25, 2020

DOI: 10.17309/tmfv.2020.2.02

\begin{abstract}
The aim of the research is to develop a methodology for monitoring and analyzing attacks of highly qualified football teams, taking into account various models of the game tactics.

Material and methodology. The competitive activity of the national football teams at the 2018 World Cup was studied. Research methodology: analysis and generalization of the literature sources, lesson observation, video analysis of competitive activities, methods of mathematical statistics.

Results. A protocol for registration attacks of the football team has been developed. The estimated scale of penetrating attacks and playing off of standard positions of the football team is identified. A different correlation of positional and fast attacks of national football teams, which used different tactical models of the game, has been established. In one half: for the tactical model "A", positional attacks were $32.3 \pm 4.35(61.8 \%)$, fast attacks $-20.0 \pm 1.78(38.2 \%)$; for the tactical model "B" - positional attacks - 25.2 \pm 4.32 (52.7\%), fast attacks - 22.6 \pm 4.32 (47.3\%); for the tactical model "C" - positional attacks - 32.5 $\pm 3.49(67.7 \%)$, fast attacks - 15.5 $\pm 3.96(32.3 \%)$; for the tactical model "D" - positional attacks $-19.2 \pm 2.87$ (41.9\%), fast attacks $-26.6 \pm 2.87$ (58.1\%). At the 2018 world Cup, out of 169 goals, 111 (65.4\%) were scored as a result of completing positional attacks, 35 (20.7\%) - after playing off of the standard positions, and 23 (13.9\%) - after implementing penalty kicks.

Conclusions. Monitoring and analyzing the attacks of a football team allows managing persistently the competitive activities of football players both at the operational level during a single game and the current level during a competitive tournament.
\end{abstract}

Keywords: football team, 2018 FIFA World Cup, positional and fast attacks, tactical models of the game..

\section{Introduction}

Competitive activity in each kind of sport is the final stage of the entire system of training sportsmen. Monitoring and analyzing the competitive activity of sportsmen can improve the effectiveness of their training management (Shynkaruk, 2013; Kostiukevych, 2016). The most difficult is to control competitive activities in team sports. First of all, this is related to the multi-factor structure of competitive activity in these sports (Kostiukevych, 2006; Doroshenko, Sushko, Koryahin, Pityn, Tkalich, \& Blavt, 2019; Mitova, 2016).

The analysis of literature sources leads to the conclusion that the problem of monitoring and analysis of competitive activities in team sports has been studied by many specialists in recent decades. In basketball, Zashchuk (2008) devoted his research to identifying the fast break models of highly qualified sportsmen in the game. The scientific research of Koryahin (2002), Bezmylova and Shynkaruk (2013) was devoted to the studying of the competitive performance indicators of high-class basketball teams. The structure of competi-

(C) Viktor Kostiukevych, Natalia Shchepotina, Tetiana Vozniuk, 2020. tive activity of qualified volleyball players of different playing roles was specified by Doroshenko (2013), Imas et al. (2017), Kostiukevych et al. (2019). Solovey et al. (2020) analyzed the results of competitive activity of highly qualified handball teams to study the development trend of the game. In field hockey, the competitive activity of both players of different roles and in the team aspect was analyzed (Fedotova, 2007; Kostiukevych, 2007; Kostiukevych et al., 2019). The features of competitive activity of players and the team in general in mini-football were studied by Stasyuk (2017).

As for football, it should be noted that the problem of analyzing and monitoring of the competitive activity in this sport has been studied by rather a wide range of specialists. Quantitative and qualitative indicators of technical and tactical activity of qualified football players (Kostiukevych et al., 2019) and highly qualified football players (Lisenchuk, 2002; Godik, 2006; Kostiukevych, 2006; Tyulenkov, 2007; Shamardin, 2013) were outlined, as well as organizational aspects of building the game tactic of the football team (Bazilevich, 2011; Bangsbo, \& Peitersen, 2000; Kostiukevych, 2020).

At the same time, the analysis of the literature confirmed the assumption that the problem of monitoring and analyz- 
ing of attacks of the football team has not been investigated enough, which defined the subject of scientific research, the results of which are presented in this article.

The aim of the research is to develop a methodology for monitoring and analyzing attacks of highly qualified football teams, taking into account various models of the game tactics.

\section{Material and methodology}

\section{Participants}

The competitive activities of the national teams that took part in the 2018 FIFA World Cup were studied. A total of 107 halves were analyzed, including 22 halves of matches of teams that used the tactical model "A", 33 halves - tactical model "B", 29 halves - tactical model "C", 23 halves - tactical model "D." The analysis of the competitive activity of the teams in one half is primarily due to the fact that a certain tactical model the team chooses, as a rule, for one half.

\section{Methodology for monitoring the attacks of a football team}

During the game, the attack carried out by the team during the match, which is divided into three types: penetrating, successful penetrating and goal-scoring.

In football, under attack should consider the actions of the team's players in the phase of possession of the ball, which are directly aimed at moving the ball in order to "take the goal" of the opposing team. Attacks in which a game situation is created for sharpening tactical move or a shot on the goal is considered penetrating. A successful attack is a penetrating attack, which ended with a kick on goal or giving a free-kick or a corner kick. A goal attack - a penetrating, which ended with a goal.

A long-term observations and analysis of the competitive activity in football allows us to come to the following conclusions:

1. As a rule, every attack in football consists of four phases (stages). The first stage is the transition of the ball to the team and the implementation of stable control of the ball. This phase can be called the stabilization phase. The stabilization stage begins after the selection or interception of the ball, as well as after the team has received the right for playing off of the standard positions. When selecting or intercepting a ball, the team must create a coalition of players to control the ball in a certain area of the field. Otherwise, the ball can very quickly pass under the control of the opposition.

A player coalition is a group of players in a team that interacts with each other in a certain playing area (zones) in order to solve a game problem.

Typically, such coalitions consist of a small number of players - from 2-3 to 4-6. In some cases, such coalitions may consist of 7-8 players. For example, for the combinations of a pass in pairs, a wall, a run, a pass through a third, a coalition of 2-3 players is necessary. Such game combinations as the transfer of the ball from flank to flank through the near, the square is held on the basis of coalitions, which consist of 4-6 players.

The main requirements for forming coalitions of players:

- the number of players in the coalition should be optimal in relation to the content and complexity of the game task;
- a coalition of players must be formed quickly enough, especially the coalition that is formed around the ball;

- coalition breaks up after it has completed its task, and the players who were in that coalition are eager to enter the new coalition;

- in each attack the number of coalitions depends on the stage of its organization and implementation: at the first stage (beginning) of the attack, usually, one coalition is created; at the second stage (attack development) - several coalitions (depending on the type of attack); 1-2 coalitions are created on the third (sharpening of the attack) and the fourth (completion of the attack).

The main rule for forming a coalition in the first stage is to form a "triangle" around the player who owns the ball. The second stage is the development of an attack with positional control of the ball (positional attacks) and fast movement of the ball in the direction of the opponent's goal (fast attacks). The third stage is the sharpening of the game situation. This stage occurs when a condition has been created for a sharpening tactical move. In other words, a penetrating attack is created. The fourth stage is the completion of the attack.

2. The third stage of the attack, that is, the stage of sharpening, can mainly take place on the following options: from the right flank; from the left flank; with the transfer of the ball into the cut between a wingback and a centre back. Conventionally, this tactical move can be defined as passing the ball to the "right pocket" and "left pocket"; the sharpening tactical move in the central part of the third zone of the field. In this case, a successful penetrating attack can be carried out by: the passing of the ball behind the back of the opponent's players; the interaction of the football players through the game combinations; the individual sharpening of the game situation. Long-range shots belong to the individual game.

The sharpening of the game situations after standard positions is registered separately (table 1).

The estimated scale of penetrating attacks is presented in the table 2 .

In football, the result of a match does not always reflect the balance of power on the field. At the same time, a team that strives to organize and conduct more attacking actions and at the same time effectively counteract the attacking actions of opponents has real opportunities to achieve a common positive result. Therefore, monitoring and analyzing the attacks of the team and the opposite team allows, in certain degree, to evaluate the effectiveness of the game of the team.

Using the scorescale (see table 2) two informative indicators that characterize the effectiveness of the team's attacks are determined - the scoring ratio (SR, standard unit) and the effectiveness of the team's attacks (ETA, points).

$$
S R=\frac{\sum_{i=1}^{n} G A}{\sum_{i=1}^{n} S A}
$$

where $\sum_{i=1}^{n} G A \quad$ - a number of goal-scoring attacks;

$$
\sum_{i=1}^{n} S A-\text { a number of successful attacks. }
$$

$E T A=\sum_{i=1}^{n}$ point $s(P A+S A+G A)$, 
Table 1. A protocol for registering attacks in football

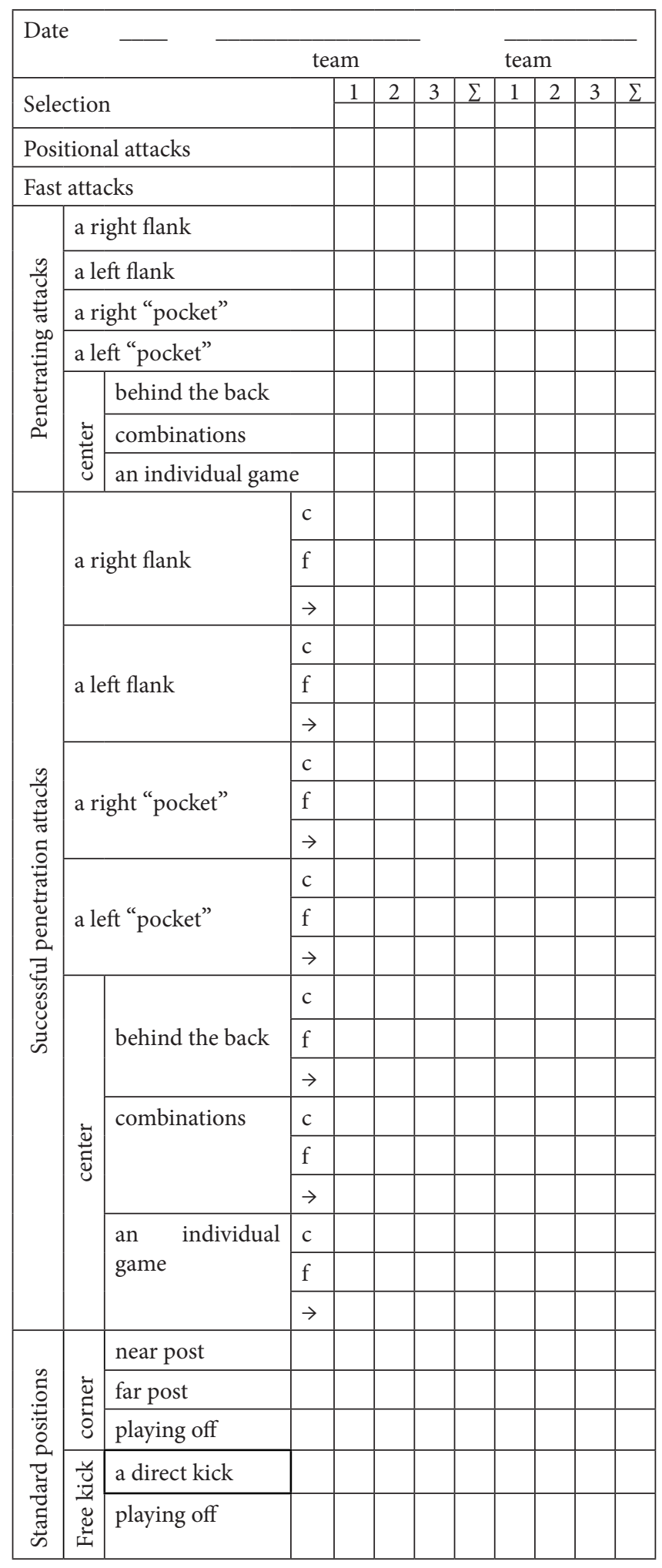

Notes: c - corner-kick; $\mathrm{f}$ - free kick; $\rightarrow$ - shot on goal; 1, 2, 3 - field zone

where $\sum_{i=1}^{n}$ point $s$ : PA - a number of penetrating attacks; SA - a number of successful attacks; GA - a number of goalscoring attacks.
It should be emphasized that the above method of identifying the effectiveness of the team's attacks in football is relatively easy to learn, but it is quite informative, especially for the coach when analyzing the game of the team.

\section{Statistical analysis}

In the mathematical treatment of the results of the study the descriptive statistics were used: the following values were defined: arithmetic mean, mean square deviation, standard error of the arithmetic mean. The mathematical processing of the results of the study was conducted using MS Excel software packages.

\section{Research results}

A focused observation of the competitive activities of highly qualified club and national teams allows us to come to the conclusion that in modern football, one or another team primarily uses certain tactics of the game. Every tactic in football is aimed at achieving a goal in a match, depending on the level of your team and the opposing team. In this regard, the coach usually solves three tasks before the game: the starting line-up for the game; the system of play and the method of play. In modern football, such systems of play are mainly used: 1-4-4-2; 1-4-5-1; 1-3-4-3; 1352 (1st digit - goalkeeper; 2 nd - defense line players; 3 rd - midfield line players; 4 th - attack line players).

As for the method of play, it can be active, passive, or combined. The active method involves playing "first number", when the team is included in the selection of the ball immediately after it is lost in each zone of the playing field. The passive method, on the contrary, is characterized by the fact that the team concedes the initiative to the opponent when losing the ball, all the players move behind the ball line and organize a concentrated defense in the first zone of the game. The game using the combined method is primarily due to the fact that when selecting the ball, the first line of team players is located in the second zone of the field, which makes it possible to rationally switch from attacking to defensive actions or vice versa, depending on whether the team owns the ball or selects it. As a rule, this method is used when playing equal-level teams.

Each tactic of the game is based on the following components:

- the game system;

- the method of the game;

- the ratio of positional attacks;

- the ratio of quick attacks;

- the ratio of holding, developing and sharpening gears;

- the ratio of high, medium and low pressure;

- the ratio of technical and tactical actions performed in various modes of coordination complexity.

Based on these components, four main tactical models of the game of highly qualified football teams can be determined: model "A", model "B", model "C", model "D". Models "A" and " $C$ " refer to the active method of playing the game, that is, to the "playmaking" method. Model " $\mathrm{D}$ " provides a game based on the passive method, and model " $\mathrm{B}$ " is used when the conditions of the combined method of playing are met.

One of the tasks of the research of competitive activity of national football teams at the 2018 world Cup was to 
Kostiukevych, V., Shchepotina, N., \& Vozniuk, T. (2020). Monitoring and Analyzing of the Attacks of the Football Team

Table 2. A scorescale for organizing and conducting attacks by a team in football

\begin{tabular}{|c|c|c|c|c|c|}
\hline \multirow{2}{*}{$\begin{array}{l}\text { Type of attacks and principles of their } \\
\text { completion }\end{array}$} & \multirow{2}{*}{$\begin{array}{l}\text { Number of } \\
\text { points per } 1 \\
\text { attack }\end{array}$} & \multicolumn{2}{|c|}{ The team } & \multicolumn{2}{|c|}{ Opposite team } \\
\hline & & $\begin{array}{c}\text { number of } \\
\text { attacks }\end{array}$ & point total & number of attacks & point total \\
\hline Penetrating - losing the ball & 1 & & & & \\
\hline $\begin{array}{l}\text { Penetrating - losing the ball, created a } \\
\text { scoring chance }\end{array}$ & 4 & & & & \\
\hline Successful - a free-kick or a corner-kick & 2 & & & & \\
\hline $\begin{array}{l}\text { Successful - a free-kick or a corner-kick, } \\
\text { created a scoring chance. }\end{array}$ & 5 & & & & \\
\hline Successful - not an accurate shot on goal. & 2 & & & & \\
\hline $\begin{array}{l}\text { Successful - not an accurate shot on goal, } \\
\text { created a scoring chance. }\end{array}$ & 5 & & & & \\
\hline Successful - an accurate shot on goal. & 5 & & & & \\
\hline $\begin{array}{l}\text { Successful - an accurate shot on goal, } \\
\text { created a scoring chance. }\end{array}$ & 8 & & & & \\
\hline Successful - a free 11-meter kick. & 8 & & & & \\
\hline Successful - a goal. & 10 & & & & \\
\hline $\begin{array}{l}\text { Standard position - a free kick or a corner } \\
\text { kick (a passing, a direct kick, a playing } \\
\text { off) }\end{array}$ & 2 & & & & \\
\hline $\begin{array}{l}\text { Standard position - a free kick or a corner } \\
\text { kick (a passing, a direct kick, a playing } \\
\text { off). Created a scoring chance. }\end{array}$ & 5 & & & & \\
\hline
\end{tabular}

determine the specifics of playing the game according to different tactical models. It was assumed that the analysis of competitive activity of highly qualified football players would confirm the previously obtained results of building the game by teams using tactical models "A", "B", "C", and "D".

It was also important to determine the indicators of penetrating attacks by football teams and in particular the aggravating stage of these attacks. During the last world Cup, the competitive activity of the leaders of national teams of different playing roles was studied. The results obtained will increase the level of knowledge of football specialists regarding the features of competitive activity of teams and players in the aspect of different tactical models, which, in turn, will increase the effectiveness of management of competitive activity of football teams.

\section{Qualitative indicators of penetrating attacks of national football teams}

Long-term monitoring of the competitive activity of highly qualified football players allows us to state that the aggravating stage of penetrating attacks mainly occurs in five variants (Fig. 1.): left flank; right flank; through the left "pocket" (the part of the field in the third zone that is located between the winger and the centre back); through the right "pocket"; through the center. When conducting the aggravating stage of penetrating attacks through the center, passes behind the back of the opponent's players, group combinations and individual play are most often used.

Indicators of penetrating attacks by national football teams are presented in table 3 .
As can be seen from the table for all tactical models, the most characteristic is the conduct of sharpening stages of penetrating attacks through the flanks, for TM " $\mathrm{A}$ " these indicators are 20.0 points in one half $(28.8 \%)$, for TM "B" -11.8 points $(23.9 \%)$ for TM “C” - 10.8 points $(23.7 \%)$ and for TM “D”- 11.0 points $(31.4 \%)$.

Most of the sharpening stages of penetrating attacks through the right and left "pocket" are observed when building a game on TM "A", respectively 3.5 points $-5.0 \%$ and 2.5 $-3.6 \%$. For TM “C”, in addition to attacks through the flanks, it is typical to use sharpening tactical moves behind the defenders -7.0 points $(15.3 \%)$. A similar tendency to conduct penetrating attacks is also typical for TM " $D$ " - 7.9 points $(15.8 \%)$, which is primarily due to the predominant use of positional attacks of the first pace and fast attacks.

Of the five options for conducting penetrating attacks, the highest quality indicators were registered when attacking through the center. So successful were penetrating attacks through the center for tactical models: TM "A" -25.8 points (37.1\%), TM “B”- 17.4 points (35.1\%), TM “ $C$ "- 14.8 points (32.4\%), TM “D”- 10.6 points $(30.3 \%)$.

During one half, the highest quality indicators of penetrating attacks are observed in teams that use the playmaking tactics of the " $\mathrm{A}$ " model -69.4 points, of which $17.6 \%$ is allocated to draws of standard positions. Indicators of other tactical models are characterized by significantly lower quality indicators. In particular, the average value of quality indicators of TM " $\mathrm{B}$ " is 49.5 points, which is 19.9 (28.6\%) less than in TM "A". For TM "C", the average value of qualitative indicators of penetration attacks is less than TM "A" by 23.7 points $(34.1 \%)$. 


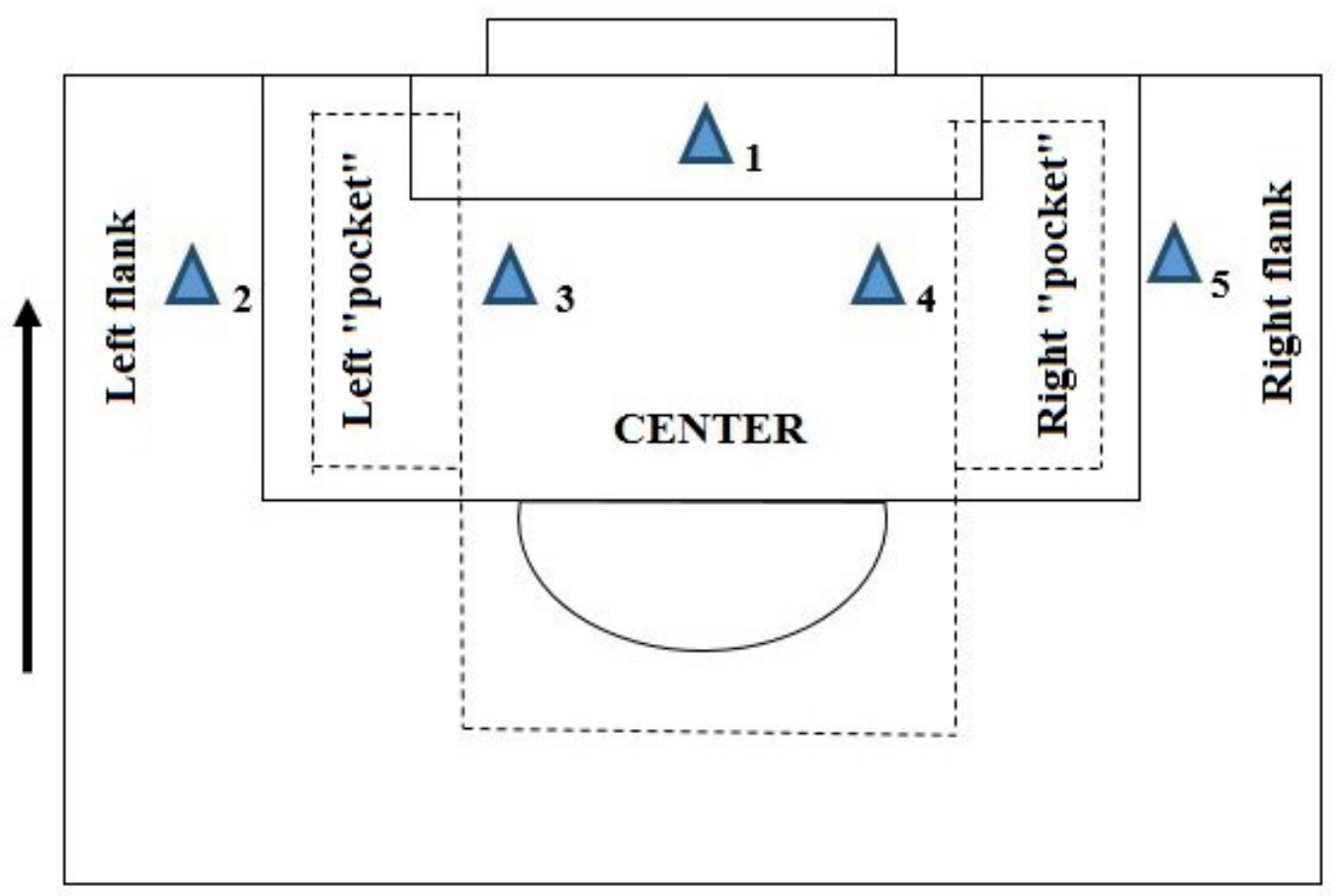

Fig. 1. Variants of the final stages of penetrating attacks in football

Table 3. Indicators of penetrating attacks by national football teams in one half at the 2018 world Cup (average values, points)

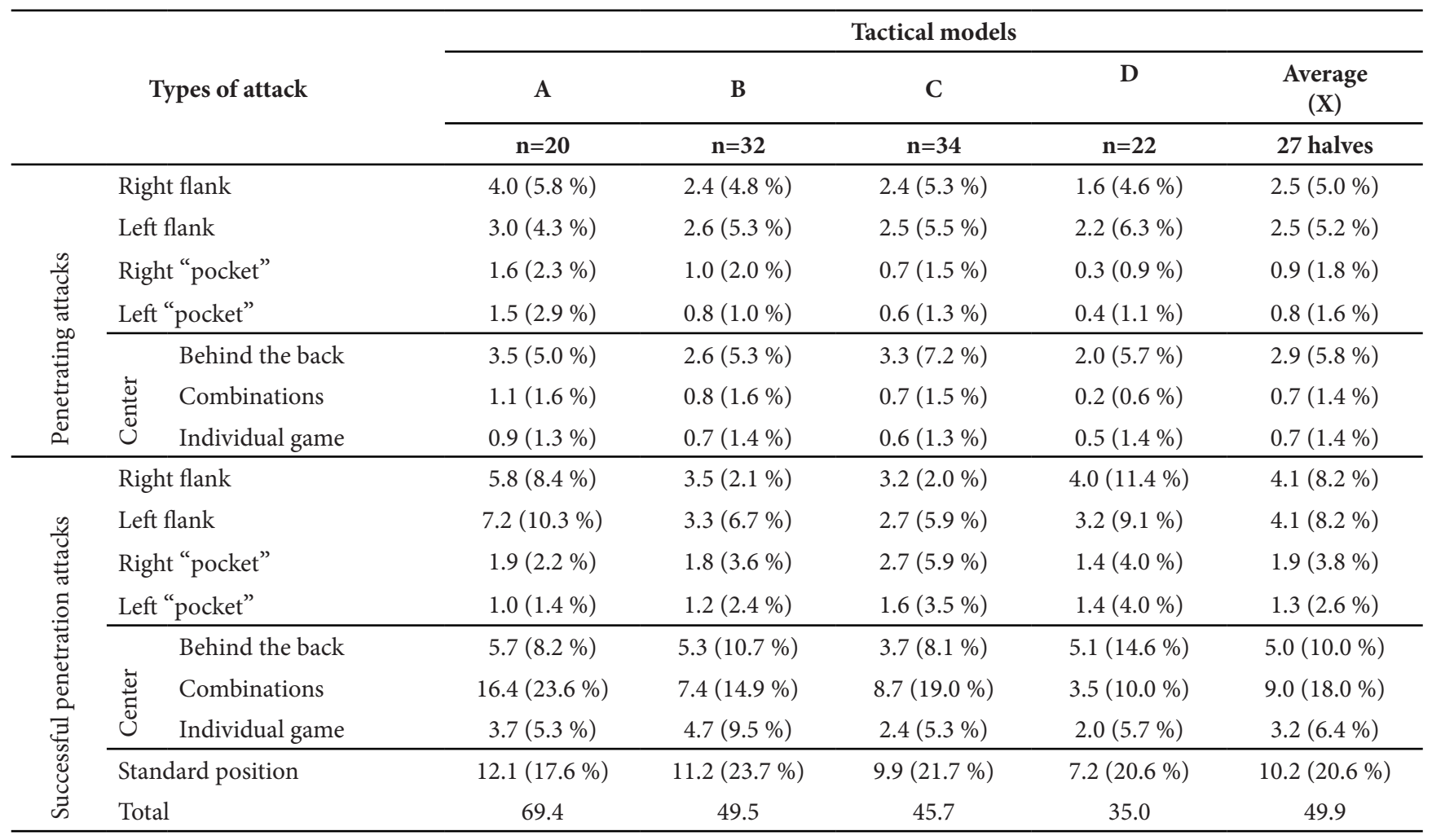

As expected, the lowest quality performance of penetrating attacks was observed in national teams that used a counter-attacking style of play. These teams built the game on TM "D". On average, for one half-time, the qualitative indicators of TM " $\mathrm{D}$ " during penetrating attacks are 35.0 points, which is 34.4 points (49.6\%) less than TM "A", 14.5 points (29.3\%) less than TM “B” and 10.7 points $(23.4 \%)$ less than TM "C".

When studying the competitive activity of football national teams at the 2018 World Cup, the indicators of positional and fast attacks were analyzed (Table 4). The most attacks were performed by teams using TM "A" - $52.3 \pm 2.56$ 
Kostiukevych, V., Shchepotina, N., \& Vozniuk, T. (2020). Monitoring and Analyzing of the Attacks of the Football Team

Table 4. Indicators of positional and fast attacks of national football teams in one half at the 2018 world Cup

\begin{tabular}{|c|c|c|c|c|c|c|c|c|c|c|c|c|c|c|c|c|}
\hline \multirow{3}{*}{ Attacks } & \multicolumn{16}{|c|}{ Tactical model } \\
\hline & \multicolumn{4}{|c|}{ “A" } & \multicolumn{4}{|c|}{ “B” } & \multicolumn{4}{|c|}{ "C" } & \multicolumn{4}{|c|}{ “D” } \\
\hline & $\mathbf{n}$ & $\mathbf{X}$ & $\mathrm{S}$ & $\%$ & $\mathbf{n}$ & $\mathbf{X}$ & $\mathrm{S}$ & $\%$ & $\mathbf{n}$ & $\mathbf{X}$ & $S$ & $\%$ & $\mathbf{n}$ & $\mathbf{X}$ & $S$ & $\%$ \\
\hline \multicolumn{17}{|c|}{ Positional attacks } \\
\hline $\begin{array}{l}\text { Of the } \\
\text { first rate }\end{array}$ & 24 & 15.3 & 4.62 & 47.3 & 33 & 11.6 & 2.88 & 46.0 & 35 & 12.0 & 2.79 & 36.9 & 22 & 10.0 & 3.14 & 52.0 \\
\hline $\begin{array}{l}\text { Of the } \\
\text { second } \\
\text { rate }\end{array}$ & 24 & 11.7 & 2.56 & 36.2 & 33 & 8.9 & 2.16 & 35.3 & 35 & 10.3 & 1.86 & 31.6 & 22 & 6.9 & 2.35 & 35.9 \\
\hline $\begin{array}{l}\text { Of the } \\
\text { third rate }\end{array}$ & 24 & 5.3 & 2.56 & 16.5 & 33 & 4.7 & 1.44 & 18.7 & 35 & 10.2 & 2.56 & 31.5 & 22 & 2.3 & 1.04 & 12.1 \\
\hline TOTAL & 24 & 32.3 & 4.35 & 61.8 & 33 & 25.2 & 4.32 & 52.7 & 35 & 32.5 & 3.49 & 67.7 & 22 & 19.2 & 2.87 & 41.9 \\
\hline \multicolumn{17}{|c|}{ Fast attacks } \\
\hline short & 24 & 7.7 & 2.05 & 38.5 & 33 & 7.8 & 1.68 & 34.5 & 35 & 5.7 & 1.86 & 36.7 & 22 & 7.1 & 1.57 & 26.6 \\
\hline average & 24 & 6.9 & 2.05 & 34.5 & 33 & 6.3 & 1.92 & 27.8 & 35 & 4.9 & 1.18 & 31.6 & 22 & 6.5 & 1.57 & 24.4 \\
\hline long & 24 & 5.4 & 1.79 & 27.0 & 33 & 8.5 & 2.40 & 37.7 & 35 & 4.9 & 1.63 & 31.7 & 22 & 13.0 & 2.09 & 49.0 \\
\hline TOTAL & 24 & 20.0 & 1.78 & 38.2 & 33 & 22.6 & 4.32 & 47.3 & 35 & 15.5 & 3.96 & 32.3 & 22 & 26.6 & 2.87 & 58.1 \\
\hline
\end{tabular}

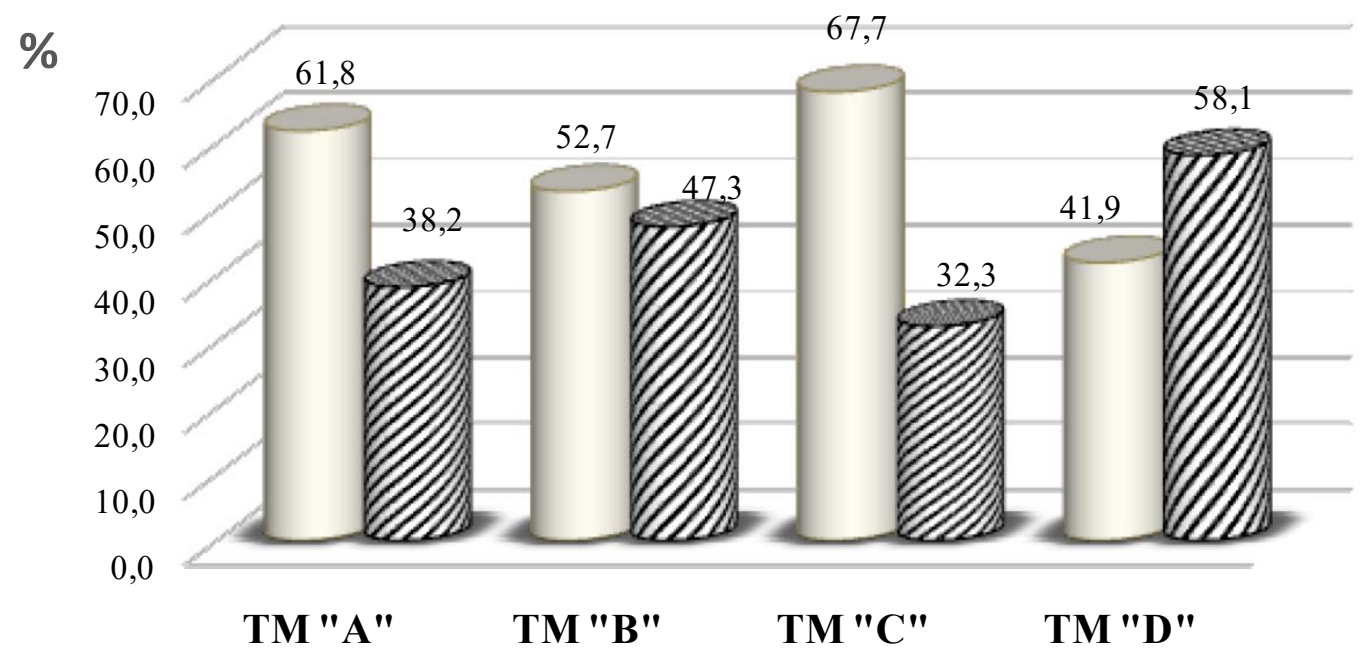

Fig. 2. Distribution of positional and fast attacks depending on different tactical models of the game of national teams at the 2018 world Cup: - positional attacks; 'Wlı. - fast attacks

attacks per one half. The teams that built the game on the basis of TM " $\mathrm{B}$ " and " $\mathrm{C}$ " have a slightly lower indicator, respectively $-47.8 \pm 1.36$ and $48.0 \pm 3.73$ attacks.

Tactical models "A", "B" and "C" are characterized by the predominant execution of positional attacks in comparison with fast attacks (Fig. 2). Teams that played on "D" performed more fast (58.1\%) than positional (41.8\%) attacks. The greatest difference between positional and fast attacks was observed in the game of teams on TM " $\mathrm{C}$ "- $35.4 \%$ and TM “A”- 23.6\%.

Indicators of the distribution of positional attacks on attacks of the first, second and third rates and fast attacks on short, medium and long (see table. 4) to a certain extent characterize the style of play of teams. Thus, TM " $A$ " is characterized by preferential execution of positional attacks of the first $(47.3 \%)$ and second (36.2\%) rates and fast short (38.5\%) and medium (34.5\%) attacks. For TM " $\mathrm{C}$ ", the distributions of positional attacks of the first, second and third rates are approximately the same, respectively, 36.9, 31.6 and $31.5 \%$. Fast attacks are also distributed for this TM: short $-36.7 \%$, medium $-31.6 \%$, and long $-31.7 \%$. To a certain extent, TM " $C$ " can be described as the most balanced tactical model of the game. It is confirmed by the construction of the game of the world's leading national teams: Spain, Germany, Argentina, and Brazil, which build the game to the greatest extent on the basis of TM "C". As can be seen from table 4, the indicators of positional and fast attacks of TM " $\mathrm{B}$ " are intermediate between TM " $\mathrm{A}$ " and TM “ $\mathrm{C}$ ". As a rule, TM “ $\mathrm{B}$ " is used by equal teams.

Unlike the first three tactical models of the game, which are characterized by the use of playmaking tactics, TM "D" is counter-attacking. With this TM, the most performed po- 
sitional attacks of the first (52.0\%) and second (35.9\%) rates and fast long $(49.0 \%)$ as well.

Thus, the indicators of positional attacks, depending on the different options for the implementation of the sharpening stages of these attacks, allow to more targeted management of the competitive activities of highly qualified football teams.

\section{Discussion}

Managing a football team during a competition is one of the most difficult problems of coaching.

First of all, this is due to the complexity of operational control, which must be carried out directly during the match. For this purpose, the coach must receive urgent objective information about the quantitative and qualitative indicators of competitive activity of both his team and the opposing team.

The proposed methodological approach to monitoring the analysis of attacks of a football team allows the coaching staff to make managerial corrections regarding:

- number of penetrating attacks;

- methods of sharpening stages of game combinations;

- quality indicators of game combinations (situations that result in a goal being scored).

Based on the data obtained, the coaching staff not only corrects the tactics of the game during the match, but also makes the necessary changes to the training program.

Therefore, our research, in addition to theoretical, is also of practical significance.

The results of our research complement the results of previous scientific searches (Godik, 2006; Kostiukevych, 2006, 2010; Shamardin, 2013; Kostiukevych, al. 2017).

At the same time, our study has provided new results on the quantitative and qualitative indicators of the tactics of football teams. For the first time, we have proposed five options for conducting the sharpening stages of penetrating attacks.

This study is a continuation of the previous scientific search for various models of tactics of football teams (Kostiukevych, 2019).

Of course, the different results in the study relate only to the first phase of the football team's tactics - the possession phase. Equally important is the second phase of the football team's game - the phase of ball selection. Research on the tactics of the team's game in the ball selection phase is very relevant and can be the subject of further scientific research.

\section{Conclusions}

Monitoring and analysis of competitive activity of athletes is the main link in the system of their training.

Modern football is characterized by a multi-factor structure of tactical interactions of players during the match. One of the key components in this structure is game combinations, in which special importance is given to penetrating attacks. The sharpening stage of these attacks is carried out in five ways: from the right flank; from the left flank; through the right "pocket"; through the left "pocket"; through the center.

The developed methodology for monitoring and analyzing the attacks of a football team is quite informative and can improve the efficiency of operational and current management decisions in the process of competitive activity.

The analysis of goals scored at the 2018 FIFA World Cup allows us to state that out of 169 goals: 25 (14.8\%) were scored after sharpening passes from the right and left flanks; $20(11.8 \%)$ - after combinations through the right and left "pocket"; 66 (38.9\%) - after combinations conducted through the center of the penalty area; $20(11.8 \%)$ - after drawing corner kicks; 15 (8.8\%) - after drawing free kicks; 23 (13.9\%) after implementing penalty kicks.

The prospect of further research of the problem under study may be due to the scientific search for the development of an integrated assessment of monitoring and analysis of the tactics of the football team.

\section{Acknowledgements}

The research was carried out within the framework of the plan of the research work of the Department of Theory and Methodology of Sports of Vinnytsia Mykhailo Kotsiubynskyi State Pedagogical University for 2016-2020 “Theoretical and Methodological Foundations of Programming and Modeling of the Training Process of Sportsmen of Different Qualifications" (state registration number 0116U005299).

\section{Conflict of interests}

The authors state that there is no conflict of interests.

\section{References}

Bangsbo, J., \& Peitersen, B. (2000). Soccer systems and strategies. Champaign, IL: Human Kinetics.

Bazilevich, O. (2011). Organizatsiya igry i podgotovka futbolistov vysokoy kvalifikatsii. Metodicheskoye posobiye. Kiev: Ukrayinskyy pysmennyk. (in Russian)

Bezmylov, N., \& Shynkaruk, O. (2013). Otsenka sorevnovatel'noy deyatel'nosti basketbolistov vysokogo klassa $v$ igrovom sezone: monografiya. Kiev. (in Russian)

Doroshenko, E., Sushko, R., Koryahin, V., Pityn, M., Tkalich, I., \& Blavt, O. (2019). The competitive activity structure of highly skilled basketball players on the basis of factor analysis methods. Human Movement, 20(4), 33-40. https://doi.org/10.5114/hm.2019.85091

Doroshenko, E.Iu. (2013). Upravlenie tekhniko-takticheskoj deiatel'nost'iu $v$ komandnykh sportivnykh igrakh: monografia. Zaporozhye: OOO “LIPS”, LTD. (in Russian)

Fedotova, E.V. (2007). Sorevnovatelnaia deiatelnost i pidgotovka sportsmenov vysokoj kvalifikacii v khokkee na trave. Kazan: "Logos Center". (in Russian)

Godik, M.A. (2006). Fizicheskaya podgotovka futbolistov. Moscow: Terra-Sport, Olimpia Press. (in Russian)

Imas, Y., Borysova, O., Shlonska, O., Kogut, I., Marynych, V., \& Kostyukevich, V. (2017). Technical and tactical training of qualified volleyball players by improving attacking actions of players in different roles. Journal of Physical Education and Sport, 17(1), 441-446.

https://doi.org/10.7752/jpes.2017.01066 
Koryahin, V. (2002). Ihrovi pokaznyky basketbolistiv. Pedahohika, psykholohiya ta medyko-biolohichni problemy fizychnoho vykhovannya i sportu, 4, 7-13. (in Ukrainian)

Kostiukevich, V. (2010). Modelirovaniye sorevnovatelnoy deyatelnosti $v$ khokkeye na trave: monografiya. Kiev: Osvita Ukrayiny. (in Russian)

Kostiukevych, V.M. (2006). Upravleniye trenirovochnym protsessom futbolistov $v$ godichnom tsikle podgotovki. Vinnitsa: Planer. (in Russian)

Kostiukevych, V. (2010). Kontrol i analiz zmahalnoyi diyalnosti v elitnomu futboli. Fizichna kul'tura, sport ta zdorovia nacii, 1, 353-360. (in Ukrainian)

Kostiukevych, V. (2019). Model indicators of collective interactions of highly qualified football players during the game. Health, Sport, Rehabilitation, 5(4), 33-40. https://doi.org/10.34142/HSR.2019.05.04.04

Kostiukevych, V. M. (2020). Models of football tactics: a monograph. Vinnytsia: LLC “TVORY”.

Kostiukevych, V., Lazarenko, N., Shchepotina, N., Kulchytska, I., Svirshchuk, N., Vozniuk, T., Kolomiets, A., Konnova, M., Asauliuk, I., Bekas, O., Romanenko, V., \& Hudyma, S. (2019). Management of athletic form in athletes practicing game sports over the course of training macrocycle. Journal of Physical Education and Sport, 19(1), 28-34. https://doi.org/10.7752/jpes.2019.S1005

Kostiukevych, V., Lazarenko, N., Shchepotina, N., Poseletska, K., Stasiuk, V., Shynkaruk, O., Borysova, O., Denysova, L., Potop, V., Vozniuk, T., Dmytrenko, S., Kulchytska, I., Konnova, M., \& Iakovenko, O. (2019). Programming of the Training Process of Qualified Football Players in the Competitive Period of the Macrocycle. Journal of Physical Education and Sport, 19(s6), 2192-2199. https://doi.org/10.7752/jpes.2019.s6329

Kostiukevych, V., Shchepotina, N., Shynkaruk, O., Kulchytska, I., Borysova, O., Vozniuk, T., Yakovliv, V., Denysova, L., Konnova, M., Khurtenko, O., Perepelytsia, O., Polishchuk, V., \& Shevchyk, L. (2019) Training process construction of the qualified volleyball women players in the preparatory period of two-cycle system of the annual training on the basis of model training tasks. Journal of Physical Education and Sport, 19(Supplement issue 2), 427-435. https://doi.org/10.7752/jpes.2019.s2063

Lisenchuk, H.A. (2002). Osobennosti sorevnovatelnoy deyatelnosti futbolistov kak faktor, opredelyayushchiy trebovaniya k kontrolyu spetsialnoy podgotovlennosti igrokov. Nauka v olimpiyskom sporte, 1, 5-11. (in Russian)

Mitova, O. (2016). Koncepciia formuvannia sistemi kontroliu $\mathrm{v}$ procesi bagatorichnogo udoskonalennia v komandnikh sportivnikh igrakh. Fizichna kultura, sport ta zdorovia nacii, 1(20), 353-360. (in Ukrainian)

Shamardin, V.M. (2013). Tekhnologhija upravlinnja systemoju baghatorichnoji pidghotovky futboljnykh komand vyshhoji kvalifikaciji. Dokt. Dys., Lviv. (in Ukrainian)

Shynkaruk, O. A. (2013). Teoriia i metodika pidgotovki: upravlinnia, kontrol, vidbir, modeliuvannia ta prognozuvannia v olimpijskomu sporti. Kyiv: NVP PolygraphService. (in Ukrainian)

Solovey, O. M., Mitova, O., Solovey, D., Boguslavskyi, V., \& Ivchenko, O. (2020). Analysis and generalization of competitive activity results of handball clubs in the game development aspect. Pedagogy of Physical Culture and Sports, 24(1), 36-43. https://doi.org/10.15561/26649837.2020.0106

Stasiuk, I. (2017). Osoblyvosti zmahalnoyi diyalnosti kvalifikovanykh hravtsiv u mini-futboli. Aktualni problemy fizychnoho vykhovannya ta metodyky sportyvnoho trenuvannya, 2, 55-59. (in Ukrainian)

Tiulenkov, S.Yu. (2007). Teoretiko-metodicheskie podkhody $k$ sisteme upravleniya podgotovkoy futbolistov vysokoy kvalifikatsii. Moscow: Physical Culture. (in Russian)

Zashchuk, S. (2005). Modelyuvannya systemy efektyvnosti zmahalnoyi diyalnosti pry shvydkomu proryvi u basketbolistiv vysokoyi kvalifikatsiyi. Teoriya i metodyka fizychnoho vykhovannya i sportu, 2-3, 11-16. (in Ukrainian) 


\title{
КОНТРОЛЬ І АНАЛІЗ АТАК ФУТБОЛЬНОЇ КОМАНДИ
}

\author{
Віктор Костюкевич ${ }^{1 \mathrm{ABCDE}}$, Наталя Щепотіна ${ }^{1 \mathrm{ABCDE}}$, Тетяна Вознюк ${ }^{1 \mathrm{ABCD}}$ \\ ${ }^{1}$ Вінницький державний педагогічний університет імені Михайла Коцюбинського
}

Авторський вклад: А - дизайн дослідження; В - збір даних; C - статаналіз; D - підготовка рукопису; Е - збір коштів

Реферат. Стаття: 9 с., 1 табл., 7 рис., 26 джерел.

У статті викладено методичний підхід до контролю й аналізу атак футбольної команди високої кваліфікації.

Мета дослідження - 3 урахуванням різних моделей тактики гри розробити методику контролю й аналізу атак футбольних команд високої кваліфікації.

Матеріал і методи. Досліджувалася змагальна діяльність національних збірних команд з футболу на чемпіонаті світу 2018 року. Методи дослідження: аналіз і узагальнення літературних джерел, педагогічне спостереження, відеоаналіз змагальної діяльності, методи математичної статистики.

Результати. Розроблено протокол реєстрації атак футбольної команди. Визначено оціночну шкалу проникаючих атак і розіграшів стандартних положень футбольної команди. Встановлено різне співвідношення позиційних і швидких атак національних збірних команд з футболу, які застосовували різні тактичні моделі гри. В одному таймі: для тактичної моделі «А» позиційні атаки становили
$32,3 \pm 4,35$ (61,8 \%), швидкі атаки - 20,0 $\pm 1,78$ (38,2 \%); для тактичної моделі «В» - позиційні атаки - 25,2 \pm 4,32 (52,7 \%), швидкі атаки - 22,6 \pm 4,32 (47,3\%); для тактичної моделі «С» - позиційні атаки - 32,5 $\pm 3,49$ (67,7 \%), швидкі атаки - 15,5 \pm 3,96 (32,3\%); для тактичної моделі «D» - позиційні атаки - 19,2 \pm 2,87 (41,9\%), швидкі атаки - 26,6 \pm 2,87 (58,1 \%). 3169 голів на чемпіонаті світу 2018 року, 111 $(65,4 \%)$ було забито в результаті завершення позиційних атак, 35 (20,7 \%) - після розіграшу стандартних положень і 23 (13,9 \%) - при реалізації 11-метрових штрафних ударів.

Висновки. Контроль і аналіз атак футбольної команди дозволяє цілеспрямовано керувати змагальною діяльністю футболістів як на оперативному рівні в процесі однієї гри, так і на поточному, протягом змагального турніру.

Ключові слова: футбольна команда, чемпіонат світу 3 футболу 2018 року, позиційні і швидкі атаки, моделі тактики гри.

\section{Information about the authors:}

Kostiukevych Viktor: kostykevich.vik@gmail.com; http://orcid.org/0000-0002-6215-764X; Department of Theory and Methodology of Sports, Vinnytsia Mykhailo Kotsiubynskyi State Pedagogical University, Ostrozhskyi St, 32, Vinnytsia, 21100, Ukraine.

Shchepotina Natalia: shchepa@mbox.vn.ua; http://orcid.org/0000-0002-9507-3944; Department of Theory and Methodology of Sports, Vinnytsia Mykhailo Kotsiubynskyi State Pedagogical University, Ostrozhskyi St, 32, Vinnytsia, 21100, Ukraine.

Vozniuk Tetiana: TV_Vinnitsa@ukr.net; http://orcid.org/0000-0002-5951-7333; Department of Theory and Methodology of Sports, Vinnytsia Mykhailo Kotsiubynskyi State Pedagogical University, Ostrozhskyi St, 32, Vinnytsia, 21100, Ukraine.

Cite this article as: Kostiukevych, V., Shchepotina, N., \& Vozniuk, T. (2020). Monitoring and Analyzing of the Attacks of the Football Team. Teoriâ ta Metodika Fizičnogo Vihovannâ, 20(2), 68-76. https://doi.org/10.17309/tmfv.2020.2.02

Received: 13.05.2020. Accepted: 20.06.2020. Published: 25.06.2020

This work is licensed under a Creative Commons Attribution 4.0 International License

(http://creativecommons.org/licenses/by/4.0). 